\title{
Cultural and Climatic Analysis: The basis of formulating compatible living environments in Oman
}

\author{
Noor Hanita Abdul Majid'1 , Hokoi Shuichi², Nozomi Takagi² \\ 1 International Islamic University Malaysia, 53100 Kuala Lumpur, Malaysia \\ University of Nizwa, Nizwa, Sultanate of Oman. \\ ${ }^{2}$ Kyoto University, Kyoto, Japan. \\ hanita@iium.edu.my
}

\begin{abstract}
Vernacular architecture has been accepted as a product that has its roots both in culture and climate. This paper examines the architectural elements of Omani houses to outline the responses towards culture and climate by analysis of house samples and survey responses. The survey gathered data on the attitude and behavior of the inhabitants along with evidence of set point temperature, operating hours and thermal sensation. The results of the analysis on design parameters of vernacular and contemporary houses, and the current behavior and attitude of occupants, suggested the basis of formulating compatible living environments in Oman.
\end{abstract}

Keywords: vernacular architecture; contemporary houses; socio-culture; climate

eISSN 2398-4295 @ 2018. The Authors. Published for AMER ABRA cE-Bs by e-International Publishing House, Ltd., UK. This is an open-access article under the CC BY-NC-ND license (http://creativecommons.org/licenses/bync-nd/4.0/). Peer-review under responsibility of AMER (Association of Malaysian Environment-Behaviour Researchers), ABRA (Association of Behavioural Researchers on Asians) and cE-Bs (Centre for EnvironmentBehaviour Studies), Faculty of Architecture, Planning \& Surveying, Universiti Teknologi MARA, Malaysia.

DOI: http://dx.doi.org/10.21834/ajbes.v3i9.64 


\subsection{Introduction}

As it is true in many different contexts, the vernacular houses of Oman are claimed to be coherent with the socio-cultural context and need to be comfortable in the hot, arid region. Vernacular architecture has been claimed by many writers to define a concept that relates to the environmental, technological and social contexts (Arbolela, 2006). Arbolela has discussed the definition of vernacular architecture with reference to many scholars including Oliver (1997) and Rapoport (1969). Fathy (1966) comprehensively expressed the relationship between socio-culture and climate to vernacular architecture. He forwarded a comprehensive definition of the vernacular wisdom stating that vernacular architecture has resulted through time and accumulated expertise. Fathy further asserted that the development of vernacular architecture has integrated local materials, climate and socioculture. These discussions show the agreement that vernacular architecture has resulted from the merging of both socio-culture and climate of a place that evolved and developed due to the needs of the society.

In Oman, the traces of vernacular buildings are still majorly evident due to the recent changes after Independence in the 1970's. Many vernacular buildings are still standing, but many are in dilapidated conditions and abandoned. The local vernacular architecture can be categorized into various building typologies; forts, castles, mosques and houses with variations depending on the location, building and material used for construction. The buildings are regional based which means that it was built as a reaction to the character and constraints of the location, climate, available material and lifestyle. The differences due to the mentioned factors are more evident in the house typology than the mosques, castles and forts. The latter typologies are much similar to each other with analogous designs and building materials. However, the houses were more distinct in styles and deeply affected by the regional factors.

\subsection{Oman Vernacular Houses}

Oman is divided into four main geographical regions which are the coastal, interior desert/oasis, mountainous and the monsoon areas of the south. These regions have different socio-culture and micro-climates. The coastal region had hot-humid climate and mainly populated by farmers and fishermen. The layouts of the houses are more spread out to respond to the climate conditions; i.e. oriented to catch breeze to assist evaporative cooling process (Fig 1). The houses often have a summer and winter (flat roofed) compartments where the summer houses are in the form of light weight construction known as khaymah or pitched roof.

The houses in the interior desert/ oasis are responding to the hot and arid conditions through having a compact layout with small openings on the building façade (Fig 2). The people of the interior is mainly farmers and craftsmen producing pottery, silver and other types of handicrafts. The houses are build from baked mud bricks with thick walls approximately $300-450 \mathrm{~mm}$ to minimize the impact of solar radiation on the buildings and the inhabitants. Simple mud-brick houses have pitched palm-frond or barristi roofs whilst the larger houses have flat earth roofs supported by palm trunks or mangrove poles. Some of the larger mud-brick houses are three stories high. 


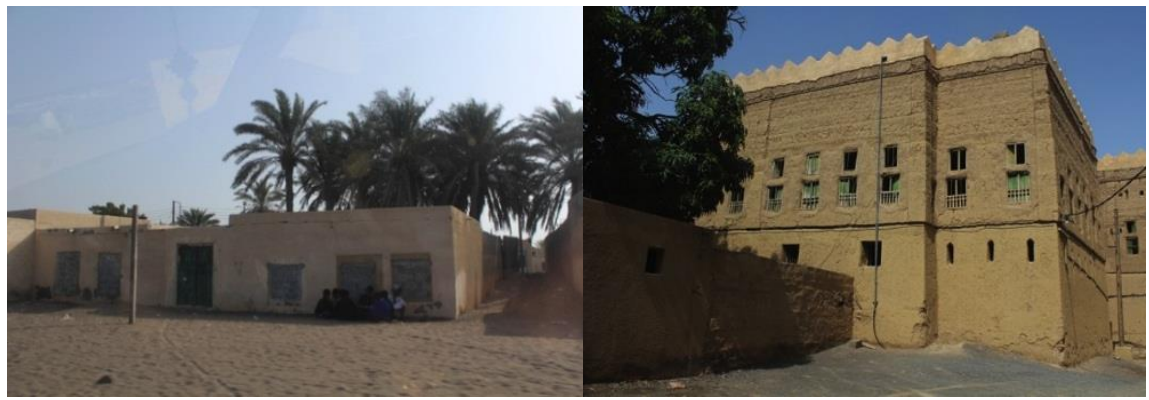

Fig. 1 A Traditional Courtyard House of the

Fig. 2 Mud Brick House at the Interior Coastal Area Made from Mud bricks (Barka, AlBatinah)

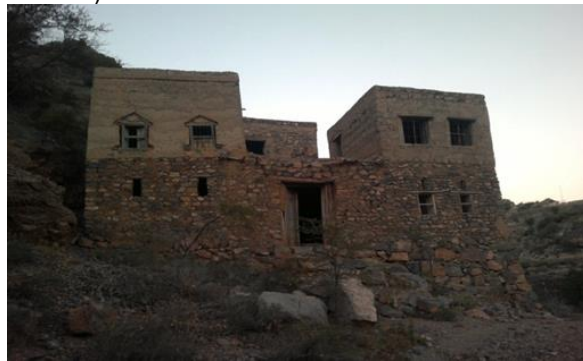

Fig. 3. A House Built from Stone in Jabal alAkhdar

Desert/Oasis Area

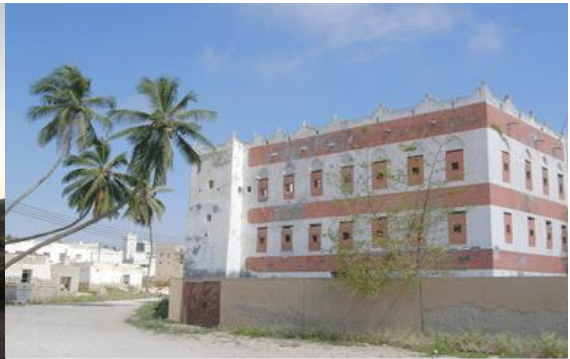

Fig. 4. A vernacular house in Southern Plains of Oman

Source:http://girlsoloinarabia.typepad.com/ph otos/15_oman/salalaholdhouse.html\#tp

On the other hand, the houses on the mountainous areas are built with stones, which are locally abundant, with compact layout with the use of thick walls (Fig 3). The houses in the interior and mountainous areas are mainly inhabited by farmers. The houses in the mountains consider the factor of warm summers and cold winters, but do not have summer and winter compartments like the houses in the coastal areas.

The traditional houses in the monsoon areas of Salalah are built with stone covered with a layer of limestone plaster. The ceiling frames are constructed from coconut trunks, and the roofs are covered with coconut palm fronds. The houses were angled to catch the sea breezes through small, attractively carved wooden windows that diffuse direct solar radiation (Fig 4). The people in the southern plains are mainly farmers, fishermen and traders.

\subsection{Climate of Oman}

man is located in between latitude $17^{\circ}-26^{\circ} \mathrm{N}$ and longitude of $51^{\circ}-57^{\circ} \mathrm{E}$. The climatic condition varies according to the region; hot and dry desert, hot and dry maritime and upland desert climate regions. Ad-Dakhliyyah or the interior region experiences the hot and dry desert climate with long summer months and a short winter. With its dry conditions, the temperature in this region has the tendency to be higher in the summer and lower in the 
winter in comparison to the coastal region. In the winter (from November until March), the climate is comfortable with temperatures as low as $10^{\circ} \mathrm{C}$ in December. In the summer, the climate is hot and dry with temperatures reaching $50^{\circ} \mathrm{C}$ in July. Precipitation is very low and concentrates in the winter when an air mass of low pressure causes rain to fall. Fig 5 shows the average data for temperature and precipitation for Nizwa (the largest city in the interior region).

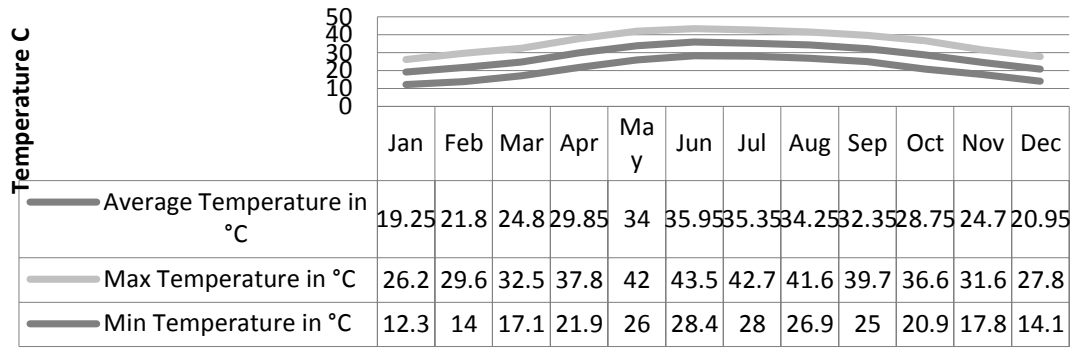

Fig.5. Yearly climatic data for Nizwa

Source: http://www.world-climates.com/city-climate-nizwa-oman-asia/

\subsection{Background}

There are a number of researches being done on vernacular architecture of Oman (Damluji, 1998; Kaushalendra, 2010; and Taylor et al., 2009). In addition, the annotated bibliography by UNESCO-ICOMOS has also cited works by Abdullak (1977) and Taylor and Vignes (1984) that reviewed vernacular houses and modern houses in Oman concerning architectural characteristics, construction techniques and conservation of some selected case studies. The vernacular wisdom has triggered many researchers to investigate further on the thermal performance of the houses and assess how the ideas can be applied. Al-Hinai et al. (1993) studied the performance of the vernacular architecture to achieve thermally comfortable spaces in Oman. Likewise, Taylor et al. (2009) assessed the possibility of applying traditional passive cooling in modern buildings. The authors suggested that vernacular architecture of Oman illustrates culturally appropriate solutions for creating comfortable interiors through utilizing natural energy from the environment. The mentioned studies set the platform for further and detailed studies of the performance of the vernacular houses due to the design of the architectural elements.

\subsection{Methodology}

This paper intends to review the vernacular houses of the Dakhliyyah region and discover their socio-cultural and climatic responses through the design (space planning and architectural elements) (Noor Hanita et al., 2009). The space planning and architectural elements will be compared to the contemporary houses to assess the extent of application 
of the vernacular ideas. The applications of the vernacular ideas in the modern buildings are suggested by Al-Hinai et al. (1993) and Taylor et al. (2009) as the means to reduce energy usage in buildings. As discussed earlier, the vernacular houses incorporated passive design solutions to achieve comfort without the use of energy. On the other hand, the new houses are designed to be dependent on the energy usage for the use of air-conditioning and fans to achieve comfort. Hence, the use of air-conditioning can be used as an indicator of dependency on energy in contemporary houses and indoor spaces are not thermally comfortable.

The analyses are representative of the desert and oasis areas, and the chosen houses are assumed to have the common features to both vernacular and contemporary houses in this region. Surveys are conducted through guided interviews. Enumerators were trained to retrieve information on households. The questionnaire surveys cover information about the occupants (no of persons; ages; etc.), the architecture of the house (to determine the house layout) and also the behavior of the occupants in relation to thermal comfort (the clothing, set temperature, thermal sensation, etc.) The complete response gained is $67 \%$ of the distributed questionnaire.

\subsection{FINDINGS}

Based on the understanding that vernacular houses have evolved from socio-cultural and climatic responses, a few design parameters have been chosen to assess the claims. The parameters are spatial planning (zoning, courtyard, segregation of gender and sizes), external features (proportion and scale, windows, doors and arches), materials (wall, floor and roof) and finishing and details (crenellations and colours). These parameters are chosen due to their prevalence in the design of houses in the region. The analyses will also include the contemporary house design in order to assess the compatibility of the houses to the vernacular ideas. Table 1 shows the summary of analysis on the mentioned parameters as gathered from site visits to vernacular and contemporary houses in Nizwa, al-Hamra, Manah, Izki and Adam.

Table 1: Summary of Analysis on Design Parameters of Vernacular and Contemporary Houses

\begin{tabular}{|c|c|c|c|}
\hline & VERNACULAR HOUSES & TYPICAL VILLA & REMARKS \\
\hline \multicolumn{4}{|c|}{ SPACE PLANNING } \\
\hline 号 & $\begin{array}{l}\text { Ground Floor } \\
\text { Public } \\
\text { Majlis } \\
\text { Private } \\
\text { Services-Storage, livestock, } \\
\text { bathroom etc. } \\
\text { First Floor } \\
\text { Semi-public } \\
\text { Majlis/ Living room (female) }\end{array}$ & $\begin{array}{l}\text { Ground Floor } \\
\text { Public } \\
\text { Majlis } \\
\text { Semi-public } \\
\text { Majlis/ Living room } \\
\text { (female) } \\
\text { Semi-private } \\
\text { Kitchen } \\
\text { Dining Room }\end{array}$ & $\begin{array}{l}\text { Not Compatible } \\
\text { The vernacular houses } \\
\text { mainly have the ground } \\
\text { floor as the service floor } \\
\text { where the male guests } \\
\text { are entertained and } \\
\text { storage for goods and } \\
\text { livestock. There are } \\
\text { houses with bathroom }\end{array}$ \\
\hline
\end{tabular}




\begin{tabular}{|c|c|c|c|}
\hline & \begin{tabular}{|l} 
Semi-private \\
Kitchen \\
Dining Room \\
Family room \\
Private \\
Bedrooms
\end{tabular} & $\begin{array}{l}\text { First Floor } \\
\text { Semi-private } \\
\text { Family room } \\
\text { Private } \\
\text { Bedrooms }\end{array}$ & $\begin{array}{l}\text { on the ground floor } \\
\text { inclusive of a well. In the } \\
\text { contemporary houses, } \\
\text { the ground floor is both } \\
\text { living and service } \\
\text { spaces. In cases where } \\
\text { the vernacular houses } \\
\text { are only on the ground } \\
\text { floor, the spaces are } \\
\text { zoned and designed with } \\
\text { the public areas near the } \\
\text { main entrance and the } \\
\text { family areas located at } \\
\text { the back, normally } \\
\text { separated by a } \\
\text { courtyard. In } \\
\text { contemporary houses } \\
\text { only the majlis is } \\
\text { separated while the rest } \\
\text { of the house is living } \\
\text { spaces of semi } \\
\text { public/private and } \\
\text { private spaces. }\end{array}$ \\
\hline 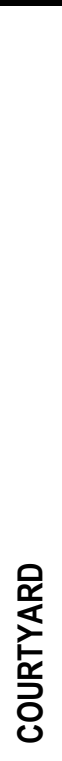 & $\begin{array}{l}\text { The vernacular houses } \\
\text { incorporated courtyards } \\
\text { within the house to separate } \\
\text { different zonings within the } \\
\text { houses. For instance, the } \\
\text { courtyards are used to } \\
\text { segregate the public areas } \\
\text { (majlis) and the semi-public } \\
\text { areas (family oriented } \\
\text { spaces). Courtyards are } \\
\text { also incorporated on the } \\
\text { upper levels as intermediate } \\
\text { areas (family activity area) } \\
\text { before the private rooms. } \\
\text { The courtyards also } \\
\text { provided daylight and } \\
\text { ventilation to the internal } \\
\text { areas of the house. Due to } \\
\text { its ratio of height and depth, }\end{array}$ & $\begin{array}{l}\text { The contemporary } \\
\text { houses no longer have } \\
\text { courtyard spaces. The } \\
\text { houses are built in a } \\
\text { compact manner with } \\
\text { introvert space planning. } \\
\text { There is no indoor- } \\
\text { outdoor connection and } \\
\text { intermediate areas where } \\
\text { the family can conduct } \\
\text { activities. Due to the } \\
\text { absence of a courtyard } \\
\text { and compact layout, there } \\
\text { is no possibility for natural } \\
\text { cooling processes } \\
\text { through convection. }\end{array}$ & $\begin{array}{l}\text { Not Compatible } \\
\text { The design of the } \\
\text { contemporary houses } \\
\text { does not cater for the } \\
\text { family members to } \\
\text { conduct activities at the } \\
\text { outdoor or intermediate } \\
\text { spaces. The houses } \\
\text { allocated family areas } \\
\text { indoors with the comfort } \\
\text { of air-conditioning and } \\
\text { modern facilities. }\end{array}$ \\
\hline
\end{tabular}




\begin{tabular}{|c|c|c|c|}
\hline & $\begin{array}{l}\text { the courtyards in the houses } \\
\text { have a positive effect on the } \\
\text { microclimate with efficient } \\
\text { shaded spaces that assist } \\
\text { convective cooling. }\end{array}$ & & \\
\hline 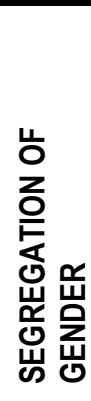 & $\begin{array}{l}\text { The houses mainly have the } \\
\text { Majlis for men accessible } \\
\text { from the outside or close to } \\
\text { the main entrance. The } \\
\text { male visitors are segregated } \\
\text { from the rest of the house } \\
\text { functions. The women's } \\
\text { domain is the family living } \\
\text { areas on the first floor. }\end{array}$ & $\begin{array}{l}\text { The villas mainly have the } \\
\text { Majlis for men accessible } \\
\text { from the outside with the } \\
\text { entrance located close to } \\
\text { the main entrance. The } \\
\text { male visitors are } \\
\text { segregated from the rest } \\
\text { of the house functions } \\
\text { with links for serving food } \\
\text { from the kitchen. }\end{array}$ & $\begin{array}{l}\text { Compatible } \\
\text { The segregation of } \\
\text { gender is maintained in } \\
\text { the contemporary } \\
\text { houses. }\end{array}$ \\
\hline $\begin{array}{l}\text { 岕 } \\
\text { ஸ }\end{array}$ & $\begin{array}{l}\text { The houses evolve through } \\
\text { time giving possibilities for } \\
\text { changes in sizes. } \\
\text { Nevertheless the rooms are } \\
\text { mostly compact and small. } \\
\text { The vernacular houses are } \\
\text { built proportionate to body } \\
\text { measurements that are } \\
\text { used to decide on height } \\
\text { and span of spaces. There } \\
\text { were no excessive sizes } \\
\text { where the rooms are small } \\
\text { and left without furniture. }\end{array}$ & $\begin{array}{l}\text { The typical villas normally } \\
\text { depended on the } \\
\text { requirements of the } \\
\text { owners. The houses are } \\
\text { built to accommodate } \\
\text { furniture. Nevertheless; it } \\
\text { was found that there are } \\
\text { wastages in the form of } \\
\text { corridor spaces that } \\
\text { increase the areas } \\
\text { unnecessarily. }\end{array}$ & $\begin{array}{l}\text { Not compatible } \\
\text { The sizes and scale is } \\
\text { not maintained in the } \\
\text { contemporary houses } \\
\text { due to available } \\
\text { technology in } \\
\text { construction. The rooms } \\
\text { are also designed to } \\
\text { accommodate furniture } \\
\text { and require more built- } \\
\text { up area to manoeuvre in } \\
\text { a given room. }\end{array}$ \\
\hline \multicolumn{4}{|c|}{ EXTERNAL FEATURES } \\
\hline 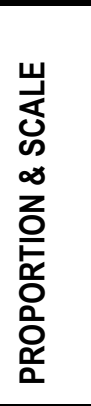 & $\begin{array}{l}\text { The houses are mainly } 2-3 \\
\text { storeys high. The houses } \\
\text { are designed as part of the } \\
\text { organic pattern of a given } \\
\text { context. Most of the time, } \\
\text { the houses link to each } \\
\text { other in clusters that are } \\
\text { meant for a big family/clan. } \\
\text { The clustered layout } \\
\text { provided mutual shading }\end{array}$ & $\begin{array}{l}\text { The contemporary } \\
\text { houses incorporated } \\
\text { many designs according } \\
\text { to the choice of the } \\
\text { owners. These houses } \\
\text { are detached villas that } \\
\text { are a result to planning on } \\
\text { a plot of land as } \\
\text { designated by the } \\
\text { government. These }\end{array}$ & $\begin{array}{l}\text { Not compatible } \\
\text { The contemporary } \\
\text { houses are designed as } \\
\text { a detached structure that } \\
\text { no longer offers the } \\
\text { same social knit } \\
\text { between the } \\
\text { communities. Houses } \\
\text { are not built next to } \\
\text { family members since it }\end{array}$ \\
\hline
\end{tabular}




\begin{tabular}{|c|c|c|c|}
\hline & $\begin{array}{l}\text { and was able to trap cool } \\
\text { night air. The scale of the } \\
\text { elevation is human in scale } \\
\text { with connected arches or } \\
\text { covered path. The openings } \\
\text { (doors and windows) are } \\
\text { small in comparison to the } \\
\text { wall areas. The façade of } \\
\text { the house is irregular with } \\
\text { very minimal decoration } \\
\text { accept for the window and } \\
\text { door carvings. }\end{array}$ & $\begin{array}{l}\text { houses have some } \\
\text { common characters that } \\
\text { are the vertical element of } \\
\text { the staircase, the } \\
\text { crenelated parapet, } \\
\text { arches and windows with } \\
\text { different details. The } \\
\text { façade details are rich } \\
\text { and have a variety of } \\
\text { designs and colours. }\end{array}$ & $\begin{array}{l}\text { is a given plot. The } \\
\text { stand-alone structure is } \\
\text { also subjected to the } \\
\text { climatic influence on all } \\
\text { sides. The elevations } \\
\text { are exposed to direct } \\
\text { sunlight with minimal } \\
\text { shading from } \\
\text { neighbouring houses. }\end{array}$ \\
\hline $\begin{array}{l}\text { n } \\
\frac{1}{3} \\
\frac{2}{3}\end{array}$ & $\begin{array}{l}\text { The windows of the } \\
\text { vernacular houses are small } \\
\text { and positioned at a higher } \\
\text { level on the ground floor to } \\
\text { allow for penetration of } \\
\text { daylight and allow for } \\
\text { natural ventilation. The } \\
\text { locations of windows at } \\
\text { higher elevation on the } \\
\text { ground floor provide visual } \\
\text { privacy from the passer-by. } \\
\text { On the first floor, the } \\
\text { windows starts just above } \\
\text { the floor level where the } \\
\text { windows offer ventilation at } \\
\text { the body level at siting } \\
\text { position. These windows } \\
\text { are set deep in the walls and } \\
\text { fixed with shutters allow for } \\
\text { versatile usage at daytime } \\
\text { and night time. }\end{array}$ & $\begin{array}{l}\text { The villas have the } \\
\text { window openings that are } \\
\text { of a standard } \\
\text { manufacturer's sizes. } \\
\text { The windows at the } \\
\text { outdoor perimeters are } \\
\text { exposed to the sun with } \\
\text { minimal shading from } \\
\text { decorative details such as } \\
\text { arches. There is a high } \\
\text { ratio of opening to the } \\
\text { wall areas. The high } \\
\text { percentage of opening } \\
\text { has allowed for heat } \\
\text { penetration. Despite the } \\
\text { use of high u-value or } \\
\text { reflective glass, the } \\
\text { internal areas suffer heat } \\
\text { gain, which adds to the } \\
\text { cooling load from air } \\
\text { conditioning during hot } \\
\text { months. }\end{array}$ & $\begin{array}{l}\text { Not compatible } \\
\text { The window placement } \\
\text { is regular regardless of } \\
\text { orientation and levels. } \\
\text { These resulted in heat } \\
\text { gain through the } \\
\text { openings that need to be } \\
\text { corrected with interior } \\
\text { furnishing or glass types. } \\
\text { Privacy factors have } \\
\text { very minimal } \\
\text { consideration on the } \\
\text { placement of windows, } \\
\text { only toilet windows are } \\
\text { placed at higher } \\
\text { elevations. }\end{array}$ \\
\hline $\begin{array}{l}\text { ำ } \\
\text { 员 } \\
\text { 음 }\end{array}$ & $\begin{array}{l}\text { Doors in the vernacular } \\
\text { houses are heavily } \\
\text { decorated and made from } \\
\text { thick hardwood. It is used to } \\
\text { provide security and act as } \\
\text { a separator while providing } \\
\text { access between spaces. }\end{array}$ & $\begin{array}{l}\text { Doors are used to provide } \\
\text { security, privacy and also } \\
\text { control the air } \\
\text { conditioning load. }\end{array}$ & Compatible \\
\hline
\end{tabular}




\begin{tabular}{|c|c|c|c|}
\hline & $\begin{array}{l}\text { The vernacular houses } \\
\text { incorporated arches at } \\
\text { openings connecting } \\
\text { spaces inside the houses } \\
\text { and as part of the window } \\
\text { details. Arches are also } \\
\text { structural elements to } \\
\text { achieve a larger span; i.e. } \\
\text { for construction of } \\
\text { staircases. }\end{array}$ & $\begin{array}{l}\text { Arches are one of the } \\
\text { most prevailing features } \\
\text { on the contemporary } \\
\text { villas. Almost all houses } \\
\text { have arches in many } \\
\text { different forms and } \\
\text { details. Arches also are } \\
\text { used for arcades, } \\
\text { doorways for external and } \\
\text { internal spaces. }\end{array}$ & $\begin{array}{l}\text { Not compatible } \\
\text { The uses of arches in } \\
\text { the contemporary villas } \\
\text { are mainly decorative } \\
\text { and not structural. }\end{array}$ \\
\hline \multicolumn{4}{|c|}{ MATERIALS } \\
\hline$\overline{\bar{K}}$ & $\begin{array}{l}\text { The walls of the vernacular } \\
\text { houses are constructed } \\
\text { using mud bricks or stones } \\
\text { at a thickness between } 300- \\
500 \mathrm{~mm} \text {. The thick wall acts } \\
\text { a thermal mass to regulate } \\
\text { the heat penetration into the } \\
\text { internal areas. The walls } \\
\text { also accommodate roznah } \\
\text { or built in cabinets for } \\
\text { storage at the interiors. }\end{array}$ & $\begin{array}{l}\text { The walls are constructed } \\
\text { with hollow concrete } \\
\text { blocks with plastering on } \\
\text { both sides. The normal } \\
\text { thickness of the walls is } \\
230 \mathrm{~mm} \text { with plastering. } \\
\text { The one layer wall is } \\
\text { heated during the day } \\
\text { and conducted heat to the } \\
\text { internal spaces. The heat } \\
\text { is trapped inside the } \\
\text { building and takes a long } \\
\text { time before it is reduced } \\
\text { through conduction due } \\
\text { to the lower temperatures } \\
\text { outside during night time. }\end{array}$ & $\begin{array}{l}\text { Not compatible } \\
\text { The contemporary } \\
\text { houses use mainly } \\
\text { reinforced post and } \\
\text { beam concrete } \\
\text { structure. Hence the } \\
\text { walls are not thick to } \\
\text { carry a load as in the } \\
\text { vernacular architecture. } \\
\text { The building envelope } \\
\text { has less thermal mass } \\
\text { capacity that causes } \\
\text { heat transfer to the inner } \\
\text { space and so, therefor, } \\
\text { overheating. Due to the } \\
\text { presence of furniture, } \\
\text { the storage is no longer } \\
\text { part of the thick walls. }\end{array}$ \\
\hline$\frac{\alpha}{\mathrm{C}}$ & $\begin{array}{l}\text { The ground floor is left bare } \\
\text { as natural earth flooring. } \\
\text { The upper floors are } \\
\text { constructed with date palm } \\
\text { trunks, mangrove wood, } \\
\text { palm fronds and finished } \\
\text { with mud. }\end{array}$ & $\begin{array}{l}\text { The floor uses concrete } \\
\text { slab with finishing of } \\
\text { choice (tiles, marble, etc.) }\end{array}$ & $\begin{array}{l}\text { Not compatible } \\
\text { The prevailing } \\
\text { construction technology } \\
\text { allows for fast and easy } \\
\text { construction of floor } \\
\text { slabs. }\end{array}$ \\
\hline
\end{tabular}




\begin{tabular}{|c|c|c|c|}
\hline ㅁㅇㅁ & $\begin{array}{l}\text { The flat roof is constructed } \\
\text { in the same manner as the } \\
\text { upper floors. The top floor is } \\
\text { often finished with a lime } \\
\text { plaster finish as the roofs } \\
\text { are mainly used for services } \\
\text { or a place of rest during } \\
\text { suitable weather conditions. }\end{array}$ & $\begin{array}{l}\text { Concrete flat roofs that } \\
\text { are used to house } \\
\text { services; water tanks } \\
\text { satellite dish, etc. } \\
\text { Sometimes the roof top is } \\
\text { also used for private } \\
\text { family gathering/activities } \\
\text { during suitable weather. }\end{array}$ & $\begin{array}{l}\text { Compatible } \\
\text { The roof mainly serves } \\
\text { the social function within } \\
\text { the family members. }\end{array}$ \\
\hline \multicolumn{4}{|c|}{ FINISHING/DETAILS } \\
\hline & $\begin{array}{l}\text { The vernacular houses of } \\
\text { the commoners have plain } \\
\text { parapet designs. Only larger } \\
\text { mansions, castles and forts } \\
\text { have crenelated parapets. } \\
\text { The approximately } 1 \text { meter } \\
\text { height parapet provides } \\
\text { privacy for the inhabitants. }\end{array}$ & $\begin{array}{l}\text { The contemporary } \\
\text { houses have } \\
\text { approximately } 1 \text { meter } \\
\text { height parapet that } \\
\text { provides privacy for the } \\
\text { inhabitants. } \\
\text { crenelated parapet is one } \\
\text { of the most common } \\
\text { features in the } \\
\text { contemporary houses. } \\
\text { The parapets have many } \\
\text { different designs applied } \\
\text { to suit the other details } \\
\text { incorporated in the } \\
\text { façade design. }\end{array}$ & $\begin{array}{l}\text { Not Compatible } \\
\text { The crenelated parapets } \\
\text { are used for castles and } \\
\text { forts as a symbol of } \\
\text { fortified architecture. In } \\
\text { the contemporary villas, } \\
\text { the crenelated parapet is } \\
\text { typically a decorative } \\
\text { element/façade } \\
\text { treatment. }\end{array}$ \\
\hline & $\begin{array}{l}\text { The colours of vernacular } \\
\text { houses are blended to the } \\
\text { landscape due to the use of } \\
\text { available materials from the } \\
\text { site. Colours are mainly } \\
\text { used in the interiors; the } \\
\text { ceiling beams are mainly } \\
\text { painted and decorated with } \\
\text { Quran verses, poetry or } \\
\text { even significant dates and } \\
\text { names of the inhabitant. } \\
\text { These writings are often } \\
\text { complemented with } \\
\text { geometric patterns as } \\
\text { decorations. }\end{array}$ & $\begin{array}{l}\text { The guidelines by the } \\
\text { Ministry suggested light } \\
\text { colours for houses with a } \\
\text { range white, beige and } \\
\text { light brown. The common } \\
\text { colours seen in the } \\
\text { environment are white } \\
\text { and earth tones; even } \\
\text { though there are some } \\
\text { vibrant colours } \\
\text { introduced in the } \\
\text { landscape. }\end{array}$ & $\begin{array}{l}\text { Not Compatible } \\
\text { Colours are not used in a } \\
\text { similar manner to the } \\
\text { vernacular houses. Due } \\
\text { to the availability of } \\
\text { paints and colours, the } \\
\text { new houses have more } \\
\text { freedom in deciding the } \\
\text { external and internal } \\
\text { finishing of the walls. } \\
\text { The interiors of the } \\
\text { contemporary houses } \\
\text { are fitted with decorative } \\
\text { ceiling of gypsum plaster } \\
\text { with many different } \\
\text { designs and choice of } \\
\text { colours. }\end{array}$ \\
\hline
\end{tabular}


The analysis on the design parameters indicated that there were socio-cultural and climatic influences in the design of both the vernacular houses and the contemporary houses. Some design parameters have been changed from the vernacular solutions to suit the changing needs of the inhabitants and availability of materials and technology. The purpose of the analysis is to note the similarities and differences of the design parameters implementation in the two house typologies and not to judge the positive or negative nature of the changes. Nevertheless, the climatic environments in the houses are expected to be altered due to changes in the proportion and scale of the openings on the facades, materials and construction technology. Based on the assumption, a further research was conducted to record the indoor environmental conditions and the behaviour of people in the contemporary houses that resulted in the air conditioning use of the house to maintain comfort.

Survey results from eighty-seven (87) assisted interviews on household in the desert and oasis areas indicated the set temperature, operating hours, thermal sensation in the contemporary houses during summer seasons. The summary of the results is presented in Fig 6, 7 and 8. The analyses of findings show that respondents preferred and set their air conditioners at very low temperatures. The highest percentage of set temperatures lies in the range of $16-20{ }^{\circ} \mathrm{C}$ at $20 \%$. It also shows that more than half respondents reported neutral to cold thermal sensation while using the air conditioner at this temperature setting. These results suggest that the indoor environment is not conducive without the use of air conditioning and the inhabitants have reacted in using an air conditioner and setting it at a low temperature. Many respondents also reported various health problems and cold sensation while they were sleeping.

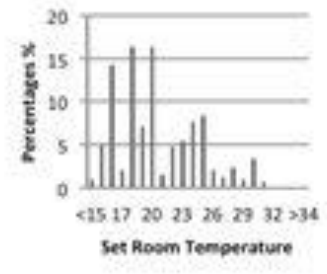

Fig. 6. The Set point Tempersiure

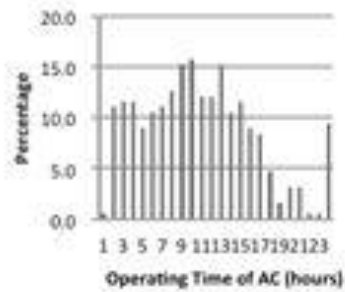

Fig. 7. Operating Hours

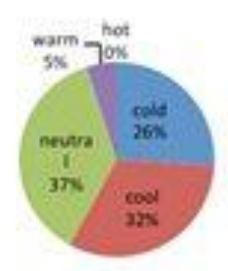

Fig. 8. The Thermel Senssion of the Oocupgrits in al Rooms

\subsection{Discussion}

The socio-cultural interpretations in the contemporary houses have changed due to changes in lifestyles. In the past, before the modernization period starting around 1970's people were mainly farmers and practiced a different daily routine. The houses accommodate storages for livestock and supplies related to the farming and rearing activities. Hence the spaces attributed to these activities no longer exist in the contemporary houses. Courtyards, which are substantial element in the vernacular houses socially and climatically, are no longer considered in the contemporary house design. The compact layout is deemed to be more 
efficient for air conditioned buildings than the courtyard houses. Nevertheless, the detached nature of the building makes the contemporary building susceptible to solar radiation due to its large exposed envelope area and has higher energy demand for cooling (St. Clair, 2009).

The changes in housing design have altered the socio-cultural and indoor environmental conditions. Although some socio-cultural requirements like segregation of gender have been retained, the behaviour of the inhabitants has changed due to the availability of modern technology. The inhabitants tend to spend more time indoors than outdoors due to preferences to a cooler environment (Fig 8). This factor is enhanced due to the layout of the house that is more indoor-oriented with comfort of modern appliances and furniture. Al-Hinai et al. (2009) have suggested that the very inefficient buildings in Oman have supported the increasingly energy profligate lifestyles. This finding is in line with the survey showing that the majority of the households spend 50.1-100 OMR on monthly electrical charges (Fig 9).

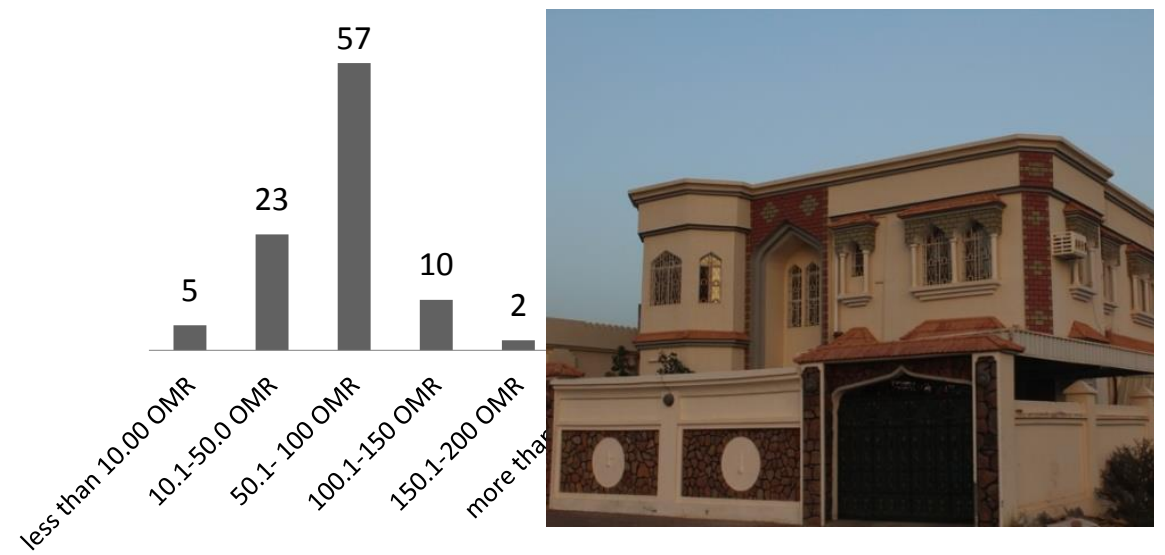

Fig. 9. Percentages of Monthly Electrical Charges for the Household
Fig. 10. Typical Contemporary Villa Design in Oman

\subsection{Conclusion}

The check and balance of the viability of the vernacular wisdom for an application today should be evaluated. Many suggestions on the climatic implementation of the vernacular ideas in the contemporary houses should be tested and evaluated in detail through simulations and field research to determine the building performances in terms of indoor environment. Questions arise on how much can the inhabitants tolerate the fluctuation and upper limits of temperature that resulted from the natural/passive cooling techniques as applied in the vernacular architecture? In addition, the human factors and behaviour are the important determining factors in the success of application of the vernacular wisdom. Climatically correct design will not be successful without the support of human behaviour and attitude. Henceforward, the results of the analysis on design parameters of vernacular and contemporary houses and the current behaviour and attitude of occupants (as forwarded in 
this paper) should be the basis of formulating compatible living environment in Oman.

\section{Acknowledgement}

The authors would like to thank University of Nizwa for the sponsorship of this research through Internal Research Funding. This research has been conducted in collaboration with the University of Kyoto and is part of a post-graduate research (Energy Usage in Omani houses). The first author is currently affiliated to the University of Nizwa, Birkat al-Mouz, Sultanate of Oman.

\section{References}

AlHinai, H., Batty, W. \& Probert, S. (1993). Vernacular architecture of Oman: Features that enhance thermal comfort achieved within buildings. Applied Energy, 44(3), 233-258. Retrieved from http://linkinghub.elsevier.com/retrieve/pii/030626199390019L

Arbolela, Gabriel (2006). What is Vernacular Architecture? Ethoarchitecture. Retrieved from http://www.vernaculararchitecture.com/

Oman - ArchNet: Islamic Architecture Community. (n.d.). Retrieved from http://archnet.org/library/dictionary/entry.jsp?entry_id=DIA0494\&mode=full

Damluji, S. (1998). The Architecture of Oman. GB: Ithaca Press.

Ibrahim, H. (2006). Environmental policies for Urban Regions at Desert Societies - Baseline Indicators for Future Ventures, Scientific Journal of Azhar University, Faculty of Engineering, Azhar University, Vol. 9, No. 3, July, 2006, Cairo, Egypt.

Kaushalendra, Singh (2010). A blend of beauty and nature care: Omani architecture. Oman Daily Observer Wed, 15 September 2010. Ed-in-chief Fahmi Bin Khalid al-Harthi.

Milmoe, M. (2012). PEARL and LEED: Carrier Hosts Green Building Rating Systems Roundtable in Middle East.Carrier Corporation. Retrieved from http://www.corp.carrier.com/Carrier+Corporate+Sites/Corporate/Side+Bar+Links/Global+News/ci.PEARL+and+LE ED\%3A+Carrier+Hosts+Green+Building+Rating+Systems+Roundtable+in+Middle+East

Noor Hanita Abdul Majid, Zaiton, Abdul Rahim \& Zuraini Denan (2009). Climate Responsive strategies versus the Cultural and Religious Dimensions in the Architecture of Malay Traditional Houses. International Conference on Construction and Industry (ICCI II 2009)

Oliver, Paul, Ed. (1997). Encyclopedia of Vernacular Architecture of the World. Vol 1. Cambridge University Press. Cited from Arbolela.

Prelgauskas, E.(1998). Enhanced Natural Ventilation In Hot Arid Lands. Environment Design Guide, Feb. DES 20, BDP, Royal Institute of Architects, Australia.

Rapoport, A. (1969). House Form and Culture. N.J.: Prentice Hall.

Sharma, A., Dhote, K.K. and Tiwari, R. (2003). Climate Responsive Energy Efficient Passive Techniques in 
Abdul Majid, N.A., et.al. / Asian Journal of Behavioural Studies (AjBeS), 3(9) Jan / Feb 2018 (p. 87-100)

Buildings. IE (I) Journal-AR. Vol 84, April. Pgs 17-26.

St. Clair, Peter (2009). Low Energy Design in the United Arab Emirates-Building Design Principles. BEDP Environment Design Guide. DES 30. Pgs. 1-10. Australia: Institute for Australian Council for Built Environment Design Professions Ltd.

UNESCO-ICOMOS Document Centre (1989). Studies and Documents on Cultural Heritage: Vernacular Architecture and its Conservation. Annotated Bibliography. 